\title{
THE FIRST TRIMESTER PRENATAL DIAGNOSIS OF POMPE'S DISEASE AT RISK
}

\author{
Michiko Ezaki, ${ }^{1}$ Kohachiro Sugryama, ${ }^{1}$ Yoshiro Wada, ${ }^{1}$ \\ and Kaoru Suzumori ${ }^{2}$ \\ ${ }^{1}$ Department of Pediatrics, Nagoya City University Medical School, \\ Mizuho-ku, Nagoya 467, Japan \\ ${ }^{2}$ Department of Obsterics and Gynecology, Nagoya City University \\ Medical School, Mizuho-ku, Nagoya 467, Japan
}

First trimester prenatal diagnosis was made for the pregnancy at risk of Pompe's disease. Chorionic villi were taken at eight weeks gestation using a biopsy forceps by ultrasound-guided transcervical collection and prepared for enzyme assay. Enzymatic activity was determined by fluorometric technique.

The parents are first cousins. The present case is the fifth pregnancy. Their second child was the propositus with Pompe's disease and the first child was suspected to have been affected by the same disease. At the third and the fourth pregnancy, amniocentesis was done. The fetus at the third pregnancy was revealed to be affected by Pompe's disease but the fetus at the fourth pregnancy was revealed not to be.

The chorionic villi provided enough material for assay of two lysosomal enzymes and for protein determination. These activities were compared to other chorionic villi taken from other normal pregnant women after getting the informed consent. As shown in Table 1, $\alpha$-1,4-glucosidase activity of chorionic villi of this case showed the intermediate level between the two control levels. $\alpha$-D-Mannosidase activity was also assayed to determine whether samples have enough lysosomal enzyme activity for an estimation. The activity was similar to those of controls.

Based on the literature to date, the present case is the first report at early prenatal diagnosis of Pompe's disease in Japan. By direct analysis of the chorionic villi, $\alpha$-1,4-glucosidase activity of the high risk was slightly higher than control 2, but on the other hand it was lower than control 1 and our previously reported normal range (Ezaki et al., 1985). We couldn't diagnose that the fetus was or was not affected by Pompes disease only by this results. The enzyme activity of the cultured villi was within normal range and we, considering this finding, diagnosed that the fetus might not be affected by Pompe's disease. The entire procedure could be done within the first trimester period. This is a major advantage of this method, since

Received February 4, 1987; revised version received June 15, 1987; Accepted July 9, 1987 
Table 1. Comparison of lysosomal enzyme activities in chorionic villi, cultured chorionic villi and cultured amniotic fuid cells.

(nmol/mg prot./h)

\begin{tabular}{|c|c|c|c|c|c|c|}
\hline \multirow{2}{*}{ Enzyme } & & \multicolumn{3}{|c|}{ Chorion biopsy specimen } & \multirow{2}{*}{$\begin{array}{c}\text { Cultured } \\
\text { villi }\end{array}$} & \multirow{2}{*}{$\begin{array}{c}\text { Cultured } \\
\text { AF cell }\end{array}$} \\
\hline & & $\begin{array}{c}\text { Pompe } \\
\text { high risk }\end{array}$ & Control 1 & Control 2 & & \\
\hline$\alpha-1,4-$ Glucosidase & $\mathrm{pH} 4.5$ & 78 & 203 & 59 & 44 & 49 \\
\hline$\alpha$-D-Mannosidase & $\mathrm{pH} 4.5$ & 85 & 51 & 63 & 94 & 70 \\
\hline$\beta$-D-Glucuronidase & pH 5.0 & $-{ }^{a}$ & - & - & 22 & 15 \\
\hline$\beta$-D-Glucosidase & $\mathrm{pH} 4.0$ & - & - & - & 27 & 30 \\
\hline$\alpha$-D-Galactosidase & $\mathrm{pH} 4.5$ & - & - & - & 77 & 46 \\
\hline$\beta$-D-Galactosidase & $\mathrm{pH} 4.5$ & - & - & - & 597 & 499 \\
\hline Total hexosaminidase & $\mathrm{pH} 6.0$ & - & - & - & 1,852 & 862 \\
\hline
\end{tabular}

a Not tested.

it spares the time with psychological burden and reduces the possibility of grave complications accompanied by induced abortion after the mid-trimester of pregnancy.

There is, however, no reliable index yet for denying all the possibility of Pompe's disease by this method, and amniocentesis was also performed for the confirmation with the parents informed consent. Cultured chorionic villi and cultured amniotic fluid cells were compared to one another on $\alpha$-1,4-glucosidase $\mathrm{pH}$ profile and several lysosomal enzyme activities. Seven lysosomal enzyme activities of them are shown in Table 1. There is no remarkable difference between them, and the activity levels are compatible with the reported ones (Gatti et al., 1984; Ezaki et al., 1985). Thus, these two materials have similar characteristics in terms of lysosomal enzymes. Besançon reported the affected case that $\alpha$-1,4-glucosidase activity of the chorionic villi showed $51 \mathrm{nmol} / \mathrm{mg}$ prot./h. This result was confirmed by post-abortion fetal tissue (3.8 nmol/mg prot./h) (Besançon et al., 1985). In our case this enzyme showed lower activity like Besançon's case but we couldn't diagnose only by direct analysis of chorionic villi because one of the two controls (control 1) showed similar activity. We consider that it is desirable to have at least two controls and that confirmation by cultured chorionic villi may be a reliable way. This method was therefore considered useful for the earlier prenatal diagnosis of Pompe's disease.

Recently, we confirmed the above diagnosis by using leukocyte at her three months old.

\section{REFERENCES}

Besançon, A., Castelnau, L., Nicolesco, H., Dumez, Y., and Poenaru, L. 1985. Prenatal diagnosis of glycogenosis type (Pompe's disease) using chorionic villi biopsy. Clin. Genet. 27: 479-482 
Ezaki, M., Sugiyama, K.. Wada, Y., and Suzumori, K. 1985. Lysozomal enzyme assay of chrionic villi in the first trimester of pregnancy as an early index for prenatal diagnosis of metabolic disorders. Nagoya Med. J. 30: 163-167.

Gatti, R., Lombardo, C., Filocamo, M., Borrone, C., and Porro, E. 1984. Comparison of the activities of 15 lysosomal enzymes in chorionic villi and cultures amniotic fluid cells. In First Trimester Fetal Diagnosis, Fraccaro, M., Simoni, G., and Brambati, B., eds., Springer-Verlag, Berlin/Heiderberg/New York/Tokyo, pp. 238-241. 